\title{
Optimum plot size and number of replications related to selective precision
}

\author{
Tamanho ótimo de parcela e número de repetições relacionados à acurácia seletiva
}

\author{
Lindolfo Storck $^{\mathrm{I*}}$ Sidinei José Lopes ${ }^{\mathrm{I}}$ Alessandro Dal'Col Lúcio ${ }^{\mathrm{I}}$ \\ Alberto Cargnelutti Filho
}

\begin{abstract}
Planning agricultural trials and evaluating their precision is important in determining the credibility of the results obtained from the research. There are various methods for estimating optimum plot size and various statistics used to measure precision. Selective precision has been cited recently as being an adequate measurement for evaluating experimental precision. The aim of this study is to propose a modification in the way the optimum plot size is estimated, related to the variability of the experimental area and prefixed selective precision. The method was applied to a set of six trials with potatoes. The optimum plot size, which was estimated on the basis of the relation between the variation coefficients and different plot sizes, can be estimated by considering simultaneously and in a prefixed way, the number of replications and the selective precision related to the treatments that are being evaluated. The optimum plot size for potato varies between four and thirteen hills, depending on the number of repetitions and the selective precision that will be used.
\end{abstract}

Key words: measurements of precision, experimental planning, plot size.

\section{RESUMO}

Planejar os ensaios e avaliar a magnitude da precisão experimental é importante para determinar o nível da credibilidade dos resultados obtidos na pesquisa. Existem diversos métodos para estimar tamanho de parcela e diferentes estatísticas como medida de precisão. Recentemente, a acurácia seletiva tem sido mencionada como sendo uma estatística adequada para avaliar a precisão experimental. $O$ objetivo deste trabalho é propor uma estimativa do tamanho ótimo de parcela relacionado à variabilidade da área experimental e à acurácia seletiva pré-fixada. O método foi aplicado a um conjunto de seis ensaios com batata. O tamanho ótimo de parcela, que era estimado a partir da relação entre o coeficiente de variação e o tamanho de parcela, pode ser estimado considerando, simultaneamente e de forma pré-fixada, o número de repetições e da acurácia seletiva referente aos tratamentos que estão sendo avaliados. O tamanho ótimo de parcela para batata varia entre quarto e treze covas, dependendo do número de repetições e da acurácia seletiva fixada.

Palavras-chave: medidas de precisão, planejamento experimental, tamanho de parcela.

\section{INTRODUCTION}

Planning agricultural trials and correctly evaluating their precision is important in determining the degree of credibility of the results obtained from the experiment. Studies related to establishing critical values for experimental precision, with the aim of carrying out trial quality control and establishing criteria or methods for classifying the precision of experiments based on trial set variation coefficients, have been published (GARCIA, 1989; AMARAL et al., 1997; LÚCIO et al., 1999; CLEMENTE \& MUNIZ, 2002; COSTA et al., 2002; CARVALHO et al., 2003; OLIVEIRA et al., 2009). Values that are critical and of defined precision vary as a function of the criterion used, the characteristic evaluated, the processes evaluated, type of management used and the set of experiments analyzed, among other things.

IDepartamento de Fitotecnia, Centro de Ciências Rurais (CCR), Universidade Federal de Santa Maria (UFSM), 97105-900, Santa Maria, RS, Brasil. E-mail: lindolfo@ pq.cnpq.br.*Autor para correspondência. 
In addition to the variation coefficient, other statistics for this purpose were studied by CARGNELUTTI FILHO \& STORCK (2007). Furthermore, selective precision as described in RESENDE \& DUARTE (2007) can play an important role in experiment quality control. In this sense, CARGNELUTTIFILHO \& STORCK (2009), in studying the precision of 101 trials on maize, concluded that the class limits established, based on such statistics as selective precision, heritability coefficient, determination coefficient and $\mathrm{F}$ test value for cultivar are adequate for estimating the degree of experimental precision of cultivar competition trials.

The selective precision statistic (SP) corresponds to the linear correlation between the genotypic and phenotypic values, $\mathrm{SP}=(1-1 / \mathrm{F})^{1 / 2}$. The value of SP depends on the magnitude of the experimental error coefficient (CVe), number of replications $(\mathrm{J})$ and the genetic variation coefficient $(\mathrm{CVg})$ that is associated with the character being evaluated. Experiments with an SP of between 0.90 and 1 are considered to be of high precision (RESENDE \& DUARTE, 2007).

On the other hand, methodologies and applications to estimate the optimum plot size (SMITH, 1938, MEIER \& LESSMAN, 1971; LOPES et al., 2005; OLIVEIRA et al., 2006; BRUM et al., 2008) are based on the non-linear relation $\mathrm{CV}(\mathrm{x})=\mathrm{A} / \mathrm{X}^{\mathrm{B}}$, where $\mathrm{CV}(\mathrm{x})$ are the variation coefficients for plots planned at different sizes (X), expressed as a number of basic units. The point of maximum curvature (Xo) of the function $\mathrm{CV}(\mathrm{x})=\mathrm{A} / \mathrm{X}^{\mathrm{B}}$ is considered to be the optimum plot size (MEIER \& LESSMAN, 1971). In this method, for values of $\mathrm{X}$ higher than Xo, the drop in $\mathrm{CV}(\mathrm{x})$ is slight and not very efficient for reducing experimental error.

Bearing in mind that the SP statistic is a function of $\mathrm{CVg} / \mathrm{CVe}$ and $\mathrm{J}$ (RESENDE \& DUARTE, 2007), it is possible to rewrite function $C V(x)=A / X^{B}$, incorporating the values of $\mathrm{CVe}$, with predefined values of $\mathbf{J}$ and SP. Thus, by fixing the selective precision magnitude and the number of replications in planning an experiment, and knowing the environmental variability (A and $B$ ) of the area chosen, we can prepare an adequate experimental plan by combining the number of replications and the plot size.

Some recent articles (COSTA et al., 2008a; COSTAet al., 2008b; ALVES \& RESENDE, 2008; ASSIS et al., 2008; PETEK et al., 2008; CARGNELUTTIFILHO \& STORCK, 2009) refer to the selective precision statistic as a measurement of precision or experimental quality for the selection of genotypes.

Thus, the objective of this study is to propose a modification in the way optimum plot size is estimated, related to the variability of the experimental area and prefixed selective precision.

\section{MATERIAL AND METHODS}

We used the results of potato tuber yield from a seed potato production area, at the experimental station of the Fundação Estadual de Pesquisa Agropecuária (FEPAGRO) in Júlio de Castilhos, State of Rio Grande do Sul, Brazil.

A total of 3456 hills, 24 rows of 144 hills (columns) was split into six lots of 12 rows of 48 hills (columns). Plots of different shapes and sizes were planned for each lot (Table 1 - first three columns). Thus, plots with different numbers of rows (width) and hills (columns or length) form plots of $\mathrm{X}$ basic units $(\mathrm{BU}=$ hill) and the number of plots of size $\mathrm{X}(\mathrm{N}(\mathrm{x}))$ was limited to a total of $576 \mathrm{BU}$.

Based on the yield obtained for each plot size, we estimated the variation coefficient $(\mathrm{CV}(\mathrm{x}))$. The function $\mathrm{CV}(\mathrm{x})=\mathrm{A} / \mathrm{X}^{\mathrm{B}}$ was adjusted using logarithmic transformation and weighting by degrees of freedom (N(x)-1). Also, the null hypothesis Ho:B=0 was tested by Student's t according STEEL et al. (1997). The optimum plot size or maximum curve (Xo) of the $\mathrm{CV}(\mathrm{x})=\mathrm{A} / \mathrm{X}^{\mathrm{B}}$ function was estimated using the following expression:

$X o=\left[\frac{A^{2} B^{2}(2 B+1)}{B+2}\right]^{1 /(2 B+2)}$ (MEIER \& LESSMAN, 1971).

Once the values of SP and $\mathrm{J}$ are predefined in the expression (RESENDE \& DUARTE, 2007) $S P=\left(1-\frac{1}{1+J C V r^{2}}\right)^{0,5}$, it is possible to isolate the value 
Table 1 - Variation coefficients $(\mathrm{CV}(\mathrm{x}))$ estimated for plots of different sizes $(\mathrm{X})$ by grouping neighboring plots in the rows $(\mathrm{F})$ and lengths (C), number of replications $(\mathrm{N})$, for the production of potato tubers, in six lots of 12 rows with 48 hills, estimates of the parameters of function $\mathrm{CV}(\mathrm{x})=\mathrm{A} / \mathrm{X}^{\mathrm{B}}$, determination coefficient $\left(\mathrm{r}^{2}\right)$ and optimum plot size $(\mathrm{Xo})$.

\begin{tabular}{|c|c|c|c|c|c|c|c|c|c|}
\hline \multirow{2}{*}{$\mathrm{F}$} & \multirow{2}{*}{$\mathrm{C}$} & \multirow{2}{*}{$X$} & \multirow{2}{*}{$\mathrm{N}(\mathrm{x})$} & \multicolumn{6}{|c|}{ 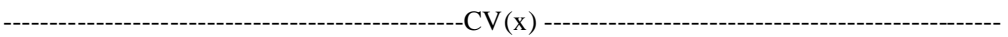 } \\
\hline & & & & Lot 1 & Lot 2 & Lot 3 & Lot 4 & Lot 5 & Lot 6 \\
\hline 1 & 1 & 1 & 576 & 32.922 & 27.171 & 43.940 & 27.760 & 37.406 & 35.623 \\
\hline 1 & 2 & 2 & 288 & 23.717 & 19.469 & 34.829 & 20.650 & 31.475 & 27.647 \\
\hline 1 & 3 & 3 & 192 & 21.316 & 17.170 & 32.472 & 20.054 & 29.459 & 27.343 \\
\hline 1 & 4 & 4 & 144 & 19.902 & 15.737 & 29.719 & 17.929 & 28.104 & 26.300 \\
\hline 1 & 6 & 6 & 96 & 18.185 & 13.931 & 27.490 & 16.849 & 27.358 & 25.077 \\
\hline 1 & 8 & 8 & 72 & 17.104 & 12.960 & 26.921 & 15.580 & 26.620 & 24.363 \\
\hline 1 & 9 & 9 & 64 & 15.843 & 12.982 & 28.687 & 16.986 & 25.934 & 26.546 \\
\hline 1 & 12 & 12 & 48 & 15.671 & 11.878 & 25.411 & 14.206 & 25.800 & 23.414 \\
\hline 2 & 2 & 4 & 144 & 18.041 & 14.182 & 23.797 & 16.831 & 21.490 & 21.055 \\
\hline 2 & 3 & 6 & 96 & 15.572 & 13.222 & 22.680 & 16.790 & 19.340 & 20.815 \\
\hline 2 & 4 & 8 & 72 & 14.645 & 12.345 & 20.504 & 15.720 & 18.345 & 20.330 \\
\hline 2 & 6 & 12 & 48 & 13.714 & 11.199 & 19.167 & 14.787 & 17.643 & 19.728 \\
\hline 2 & 8 & 16 & 36 & 12.998 & 10.511 & 18.456 & 13.894 & 17.156 & 19.437 \\
\hline 2 & 9 & 18 & 32 & 11.295 & 10.651 & 20.037 & 15.466 & 15.956 & 21.120 \\
\hline 2 & 12 & 24 & 24 & 12.244 & 9.917 & 17.067 & 12.857 & 16.410 & 18.736 \\
\hline 3 & 3 & 9 & 64 & 13.939 & 11.657 & 19.629 & 12.454 & 12.772 & 17.110 \\
\hline 3 & 4 & 12 & 48 & 13.070 & 10.857 & 17.644 & 11.418 & 12.027 & 16.617 \\
\hline 3 & 6 & 18 & 32 & 12.797 & 10.009 & 16.309 & 10.635 & 11.432 & 16.002 \\
\hline 3 & 8 & 24 & 24 & 11.767 & 9.626 & 15.369 & 9.887 & 10.414 & 15.927 \\
\hline \multirow[t]{5}{*}{3} & 12 & 36 & 16 & 10.978 & 9.029 & 14.448 & 9.042 & 10.947 & 15.093 \\
\hline & & & A & 31.63 & 25.89 & 43.54 & 26.88 & 38.50 & 34.46 \\
\hline & & & B & $0.3381^{*}$ & $0.3435^{*}$ & $0.3060^{*}$ & $0.2769^{*}$ & $0.3131 *$ & $0.2280^{*}$ \\
\hline & & & $\mathrm{r}^{2}$ & 0.996 & 0.970 & 0.906 & 0.926 & 0.778 & 0.836 \\
\hline & & & Xo & 5.19 & 4.50 & 6.33 & 4.15 & 5.82 & 4.51 \\
\hline
\end{tabular}

*Significant $(\mathrm{Ho}: \mathrm{B}=0)$ for the $\mathrm{t}$ test at $5 \%$ probability.

of $C V g$ in the relation $C V r=C V g / C V e$ (VENCOVSKY, 1987). The value of CVe is known to be CVe(x) or CV(x) for a given plot size $(\mathrm{X})$. The value of $C V g$ is the genotypic variation coefficient and is estimated using $\mathrm{CVg}=100 \hat{\sigma}_{g}^{2}$ /average, where $\hat{\sigma}_{g}^{2}$ is the estimated genotypic variance, $\hat{\sigma}_{g}^{2}=(\mathrm{QMg}-\mathrm{QMe}) / \mathrm{J}$, whose magnitude and relation depends on the plot size $(\mathrm{X})$.

Thus, function $\mathrm{CV}(\mathrm{x})=\mathrm{A} / \mathrm{X}^{\mathrm{B}}$ can be rewritten in an equivalent form as $C V g(x)=C V e(x) \sqrt{T}$, where $T=T_{(S P ; J)}=\left(\frac{1}{1-S P^{2}}-1\right) / J$. For a given combination of SP and $\mathrm{J}$, the value of T is fixed for all values of $\mathrm{X}$ in the function $C V g(x)$. It is known that by multiplying all values of a dependent variable by a constant, the value of the average or origin of the function (A) is multiplied by this constant and the shape of the curve (angular coefficient $=\mathrm{B}$ ) remains unchanged. For this reason, $C V g(x)=A^{\prime} / X^{B}$, where $A^{\prime}=A \sqrt{T}$. Consequently, the point of maximum curvature of function $C V g(x)=A^{\prime} / X^{B}$ is obtained using the expression $X g=\left[\frac{T A^{2} B^{2}(2 B+1)}{B+2}\right]^{1 /(2 B+2)}$ or, simply $X g=X o[T]^{1 /(2 B+2)}$. The value $X g$ is the point of maximum curvature of function $C V g(x)=A^{\prime} / X^{B}$ or the optimum plot size, expressed as the number of basic units (BU), for different values of $\mathrm{J}$ and SP. Thus, the optimum plot size which was estimated using the relation of $\mathrm{CV}(\mathrm{x})$ to $\mathrm{X}$, is now also estimated taking as predefined the number of replications $(\mathrm{J}=4,5$ and 8$)$ and the selective precision ( $\mathrm{SP}=0.90$ up to $\mathrm{SP}=0.99)$ referent to the material that is being evaluated. 


\section{RESULTS AND DISCUSSION}

For the six lots of uniformity trials, non-linear function $\mathrm{CV}(\mathrm{x})=\mathrm{A} / \mathrm{X}^{\mathrm{B}}$ was significantly adjusted $(5 \%)$, with an average determination coefficient of 0.902 (Table 1). In all lots, the values of $\mathrm{CV}(\mathrm{x})$ drop as the plot size $(\mathrm{X})$ increases, in accordance with the estimates of the parameters (A e B) of the adjusted function. Optimum plot size (Xo) varies between four and six hills, with an average of five hills per plot. The values of the yield heterogeneity index (b) that correspond to two times estimate B (OLIVEIRA et al., 2006), vary in the intermediate range (b between 0.456 and 0.687 ), values in which the correlation between neighboring plots is moderate and considered to be an adequate situation for planning experiments, simultaneously varying the number of replications and the plot size (LIN \& BINNS, 1986).

For SP varying between 0.90 and 0.99 and for $\mathrm{J}$ equal to 4, 6 and 8 replications, the estimates of the parameters in the relation $C V g(x)=A^{\prime} / X^{B}$ and the respective optimum plot size $(\mathrm{Xg})$, referent to the data of the $\mathrm{CV}(\mathrm{x})$ of lot 1 , are given in table 2. It can be seen that, as confirmed in the methodology, the origin of the curve was altered ( $A^{\prime}=A \sqrt{T}$ ), and estimates of $\mathrm{B}$ and the determination coefficient $\left(\mathrm{r}^{2}=0.99\right)$ do not vary with the values of SP and $\mathrm{J}$.

Considering that optimum plot size (point of maximum curvature of the function) is influenced more by the value of A than by the value of $\mathrm{B}$ (OLIVEIRA et al., 2006), despite the fact that the correlation between $\mathrm{A}$ and $\mathrm{B}$ is linear, positive and significant, the value of $\mathrm{Xg}$ will depend only on the values of SP and J within the same lot of experimental units under evaluation. In this methodology, the yield heterogeneity index or correlation between neighboring plots estimated in function $\mathrm{VU}(\mathrm{x})=\mathrm{V} 1 / \mathrm{X}^{\mathrm{b}}$, proposed by $\operatorname{SMITH}(1938)$, that can be estimated as $b=2 B$ (OLIVEIRA et al., 2006) has less influence on the magnitude of $\mathrm{Xg}$, although it is in the same direction. Thus, what most influences optimum plot size is the estimate of the coefficient of variation between the plots of one basic unit, added to the number of replications and the predefined selective precision.

In this case, increasing the number of replications reduces the optimum plot size and increasing SP increases the plot size. The way in which optimum plot size $(\mathrm{Xg})$ is related to $\mathrm{SP}$ and $\mathrm{J}$, based on the data from lot 1 , is shown in figure 1 ( $a$ and $b$ ). By reducing $\mathrm{SP}$, as from 0.99 , the values of $\mathrm{Xg}$ drop nonlinearly, similar to the relation $\mathrm{CV}(\mathrm{x})=\mathrm{A} / \mathrm{X}^{\mathrm{B}}$.

By fixing the value of SP, we can obtain a better combination of $\mathrm{Xg}$ and $\mathrm{J}$ for defining an experimental plan. For example, using Figure 1b, it is more appropriate (lower total area) to use plots of eight hills and three replications (total of 24 hills per treatment) than to use plots of seven hills and five replications (total of 35 hills per treatment) for the same selective precision $(\mathrm{SP}=0.95)$.

Table 3 defines optimum plot size values for 4, 6 and 8 replications and SP ranging between 0.90

Table 2 - Estimates of the parameters of function $\mathrm{CVg}(\mathrm{x})=\mathrm{A}^{\prime} / \mathrm{X}^{\mathrm{B}}$ for optimum plot size $(\mathrm{Xg})$, determination coefficient $\left(\mathrm{r}^{2}\right)$, varying the values for number of replications $(\mathrm{J})$ and selective precision (SP) in the high-precision range, for the data of lot 1.

\begin{tabular}{lcccccccccc}
\hline & & & & & & & & \\
SP & A' & B & Xg & A & B & Xg & A & B & Xg & r $^{2}$ \\
\hline 0.90 & 32.65 & 0.3381 & 5.32 & 26.66 & 0.3381 & 4.57 & 23.09 & 0.3381 & 4.10 & 0.99 \\
0.91 & 34.71 & 0.3381 & 5.56 & 28.34 & 0.3381 & 4.78 & 24.54 & 0.3381 & 4.29 & 0.99 \\
0.92 & 37.12 & 0.3381 & 5.85 & 30.31 & 0.3381 & 5.03 & 26.25 & 0.3381 & 4.52 & 0.99 \\
0.93 & 40.02 & 0.3381 & 6.19 & 32.67 & 0.3381 & 5.32 & 28.29 & 0.3381 & 4.78 & 0.99 \\
0.94 & 43.57 & 0.3381 & 6.59 & 35.58 & 0.3381 & 5.67 & 30.81 & 0.3381 & 5.09 & 0.99 \\
0.95 & 48.12 & 0.3381 & 7.10 & 39.29 & 0.3381 & 6.10 & 34.02 & 0.3381 & 5.48 & 0.99 \\
0.96 & 54.22 & 0.3381 & 7.76 & 44.27 & 0.3381 & 6.67 & 38.34 & 0.3381 & 5.99 & 0.99 \\
0.97 & 63.10 & 0.3381 & 8.70 & 51.52 & 0.3381 & 7.47 & 44.62 & 0.3381 & 6.71 & 0.99 \\
0.98 & 77.88 & 0.3381 & 10.18 & 63.59 & 0.3381 & 8.75 & 55.07 & 0.3381 & 7.86 & 0.99 \\
0.99 & 110.99 & 0.3381 & 13.26 & 90.62 & 0.3381 & 11.40 & 78.48 & 0.3381 & 10.24 & 0.99 \\
\hline
\end{tabular}

Ciência Rural, v.41, n.3, mar, 2011. 


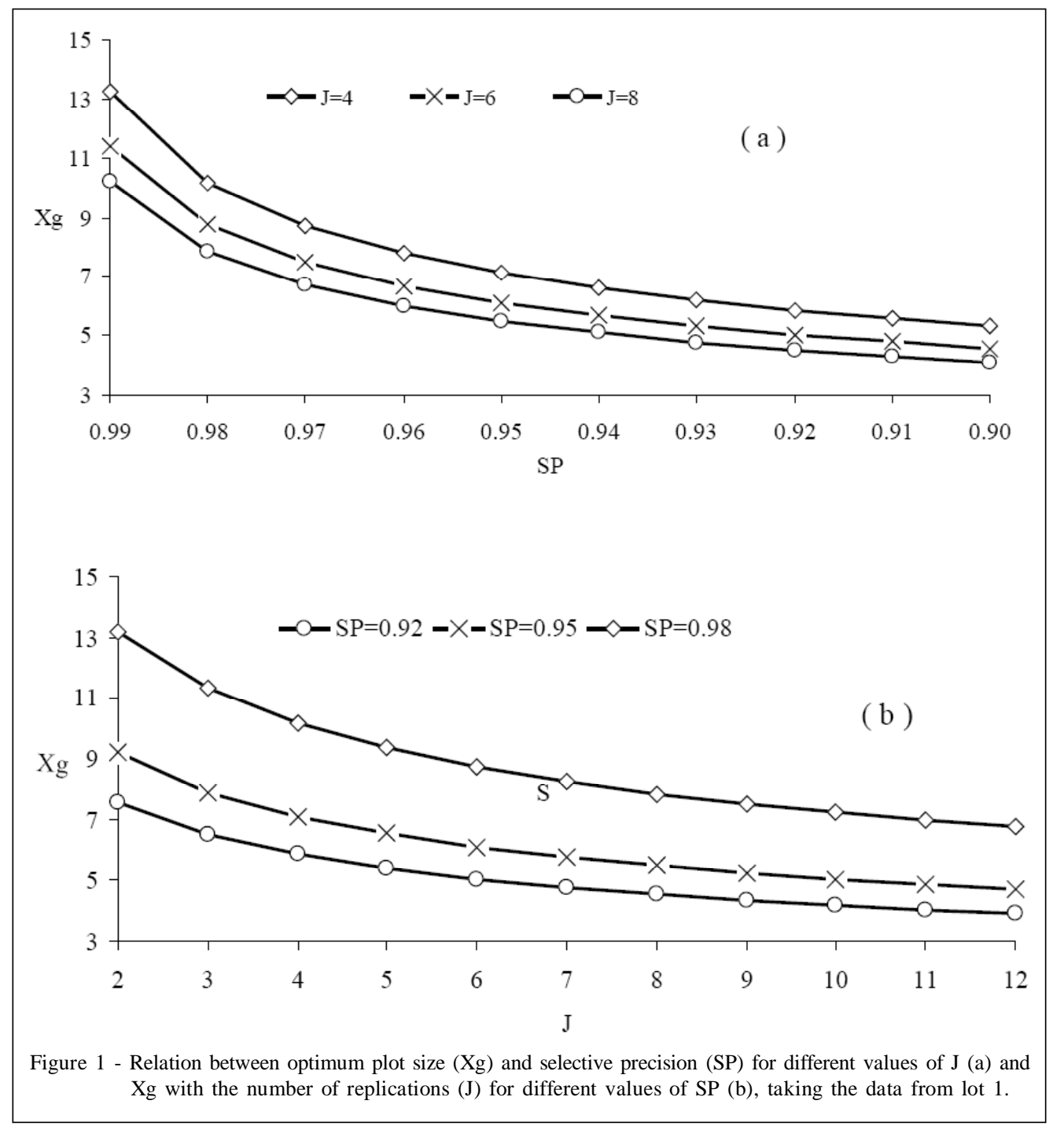

and 0.99 , for the six lots studied and the average.

Observing the values within the same row (between lots), the variations in the optimum plot size in integer terms (hills) are due to environmental variations, expressed by the value of the yield heterogeneity index $(b=2 B)$ and the coefficient of variation between the plots of one basic unit (hill). As there are six neighboring lots, it would be appropriate to use the average size to represent the experimental area. Using the average results, the optimum plot size varies between four hills ( $\mathrm{J}=8$ and $\mathrm{SP}=0.90)$ and 13 hills $(\mathrm{J}=4$ and $\mathrm{SP}=0.99)$, being criterion of the researcher the choice of the best combination for $\mathrm{Xg}, \mathrm{J}$ and SP to the experiment.

\section{CONCLUSION}

It is possible to obtain estimates of optimum plot size for field experiments taking account simultaneously of the number of replications and the proposed selective precision. Also, the optimum plot size for potato varies between four and thirteen hills, depending on the number of repetitions and the selective precision that will be used.

\section{ACKNOWLEDGEMENTS}

We would like to thank the Brazilian Council for Scientific and Technological Development (CNPq) for the research productivity grant awarded to the authors of the article. 
Table 3 - Values for optimum plot size $(\mathrm{Xg})$ based on the variation in selective precision (SP) and the number of replications (J), for the production of potato tubers in the six lots and the average.

\begin{tabular}{|c|c|c|c|c|c|c|c|c|}
\hline SP & $\mathrm{J}$ & Lot 1 & Lot 2 & Lot 3 & Lot 4 & Lot 5 & Lot 6 & Average \\
\hline 0.90 & 4 & 5.32 & 4.61 & 6.49 & 4.25 & 5.96 & 4.63 & 5.21 \\
\hline 0.91 & 4 & 5.56 & 4.82 & 6.80 & 4.46 & 6.25 & 4.86 & 5.46 \\
\hline 0.92 & 4 & 5.85 & 5.07 & 7.16 & 4.70 & 6.58 & 5.14 & 5.75 \\
\hline 0.93 & 4 & 6.19 & 5.36 & 7.58 & 4.99 & 6.96 & 5.46 & 6.09 \\
\hline 0.94 & 4 & 6.59 & 5.71 & 8.09 & 5.33 & 7.43 & 5.85 & 6.50 \\
\hline 0.95 & 4 & 7.10 & 6.15 & 8.73 & 5.76 & 8.01 & 6.35 & 7.02 \\
\hline 0.96 & 4 & 7.76 & 6.72 & 9.56 & 6.33 & 8.77 & 7.00 & 7.69 \\
\hline 0.97 & 4 & 8.70 & 7.52 & 10.74 & 7.13 & 9.85 & 7.91 & 8.64 \\
\hline 0.98 & 4 & 10.18 & 8.80 & 12.62 & 8.40 & 11.56 & 9.39 & 10.16 \\
\hline 0.99 & 4 & 13.26 & 11.46 & 16.55 & 11.09 & 15.14 & 12.54 & 13.34 \\
\hline 0.90 & 6 & 4.57 & 3.96 & 5.55 & 3.63 & 5.11 & 3.92 & 4.46 \\
\hline 0.91 & 6 & 4.78 & 4.15 & 5.82 & 3.81 & 5.35 & 4.12 & 4.67 \\
\hline 0.92 & 6 & 5.03 & 4.36 & 6.13 & 4.01 & 5.63 & 4.36 & 4.92 \\
\hline 0.93 & 6 & 5.32 & 4.61 & 6.49 & 4.26 & 5.97 & 4.63 & 5.21 \\
\hline 0.94 & 6 & 5.67 & 4.91 & 6.93 & 4.55 & 6.37 & 4.96 & 5.57 \\
\hline 0.95 & 6 & 6.10 & 5.29 & 7.47 & 4.92 & 6.86 & 5.38 & 6.00 \\
\hline 0.96 & 6 & 6.67 & 5.78 & 8.19 & 5.40 & 7.52 & 5.93 & 6.58 \\
\hline 0.97 & 6 & 7.47 & 6.47 & 9.20 & 6.08 & 8.44 & 6.71 & 7.40 \\
\hline 0.98 & 6 & 8.75 & 7.57 & 10.81 & 7.17 & 9.91 & 7.96 & 8.70 \\
\hline 0.99 & 6 & 11.40 & 9.85 & 14.17 & 9.46 & 12.97 & 10.63 & 11.41 \\
\hline 0.90 & 8 & 4.10 & 3.56 & 4.97 & 3.24 & 4.58 & 3.49 & 3.99 \\
\hline 0.91 & 8 & 4.29 & 3.73 & 5.21 & 3.40 & 4.80 & 3.67 & 4.18 \\
\hline 0.92 & 8 & 4.52 & 3.92 & 5.49 & 3.59 & 5.05 & 3.87 & 4.41 \\
\hline 0.93 & 8 & 4.78 & 4.14 & 5.81 & 3.80 & 5.35 & 4.12 & 4.67 \\
\hline 0.94 & 8 & 5.09 & 4.41 & 6.20 & 4.07 & 5.70 & 4.41 & 4.98 \\
\hline 0.95 & 8 & 5.48 & 4.75 & 6.69 & 4.39 & 6.15 & 4.79 & 5.38 \\
\hline 0.96 & 8 & 5.99 & 5.19 & 7.33 & 4.82 & 6.74 & 5.28 & 5.89 \\
\hline 0.97 & 8 & 6.71 & 5.81 & 8.24 & 5.43 & 7.56 & 5.97 & 6.62 \\
\hline 0.98 & 8 & 7.86 & 6.80 & 9.68 & 6.41 & 8.88 & 7.08 & 7.79 \\
\hline 0.99 & 8 & 10.24 & 8.85 & 12.69 & 8.46 & 11.63 & 9.45 & 10.22 \\
\hline
\end{tabular}

\section{REFERENCES}

ALVES, R.M.; RESENDE, M.D.V. Avaliação genética de indivíduos e progênies de cupuaçuzeiro no estado do Pará e estimativas de parâmetros genéticos. Revista Brasileira de Fruticultura, v.30, p.696-701, 2008. Disponível em: <http:/ $/$ www.scielo.br/scielo.php?script $=$ sci_arttext\&pid $=S 0100$ $29452008000300023 \& \operatorname{lng}=\mathrm{en} \& \mathrm{nrm}=\mathrm{iso}>$. Acesso em: $01 \mathrm{abr}$. 2010. doi: 10.1590/S0100-29452008000300023.

AMARAL, A.M. et al. Avaliação do coeficiente de variação como medida da precisão na experimentação com citros. Pesquisa Agropecuária Brasileira, v.32, p.1221-1225, 1997.

ASSIS, G.M.L. et al. Seleção de genótipos de amendoim forrageiro para cobertura do solo e produção de biomassa aérea no período de estabelecimento utilizando-se metodologia de modelos mistos. Revista Brasileira de Zootecnia, v.37, p.1905-1911, 2008. Disponível em: <http://www.scielo.br/ scielo.php? script = sci_arttext \& pid = S 1516 $35982008001100001 \& \operatorname{lng}=\mathrm{en} \& \mathrm{nrm}=\mathrm{iso}>$. Acesso em: $01 \mathrm{abr}$. 2010. doi: 10.1590/S1516-35982008001100001.
BRUM, B. et al. Tamanho ótimo de parcela para ensaios com sorgo granífero em duas épocas de semeadura. Ciência Rural, v.38, p.315-320, 2008. Disponível em: <http://www.scielo.br/ scielo.php? script=sci_art text\&pid=S $0103-$ $84782008000200003 \& \operatorname{lng}=e n \& n r m=i s o>$. Acesso em: 01 abr. 2010. doi: 10.1590/S0103-84782008000200003.

CARGNELUTTI FILHO, A.; STORCK, L. Estatísticas de avaliação da precisão experimental em ensaios de cultivares de milho. Pesquisa Agropecuária Brasileira, v.42, p.17-24, 2007. Disponível em: <http://www.scielo.br/scielo.php?script=sci_arttext\&pid=S0100204X2007000100003\&lng=en\&nrm=iso >. Acesso em: 01 abr. 2010. doi: 10.1590/S0100-204X2007000100003.

CARGNELUTTI FILHO, A.; STORCK, L. Medidas do grau de precisão experimental em ensaios de competição de cultivares de milho. Pesquisa Agropecuária Brasileira, v.44, p.111117, 2009. Disponível em: <http://www.scielo.br/ scielo.php?script=sci_arttext\&pid=S $0100-$ 204X2009000200001\&lng=en\&nrm=iso>. Acesso em: 01 abr. 2010. doi: 10.1590/S0100-204X2009000200001. 
CARVALHO, C.G.P. et al. Proposta de classificação dos coeficientes de variação em relação à produtividade e altura da planta de soja. Pesquisa Agropecuária Brasileira, v.38, p.187-193, 2003. Disponível em: <http://www.scielo.br/ scielo.php? script $=$ sci_arttext\&pid=S $0100-$ 204X2003000200004\&lng=en\&nrm=iso>. Acesso em: 01 abr. 2010. doi: 10.1590/S0100-204X2003000200004.

CLEMENTE, A.L.; MUNIZ, J.A. Avaliação do coeficiente de variação em experimentos com gramíneas forrageiras. Ciência e Agrotecnologia, v.26, p.197-203, 2002.

COSTA, N.H.A.D. et al. Novo método de classificação de coeficientes de variação para a cultura do arroz de terras altas. Pesquisa Agropecuária Brasileira, v.37, p.243-249, 2002. Disponível em: $<$ http://www.scielo.br/scielo.php?script=sci_arttext\&pid=S0100204X2002000300003\&lng=en\&nrm=iso >. Acesso em: 01 abr. 2010. doi: 10.1590/S0100-204X2002000300003.

COSTA, R.B. et al. Variabilidade genética e seleção para caracteres de crescimento da seringueira. Bragantia, v.67, p.299-305, 2008a. Disponível em: <http://www.scielo.br/ scielo.php? script = sci_art text \& pid=S $0006-$ $87052008000200005 \& \operatorname{lng}=\mathrm{en} \& \mathrm{nrm}=\mathrm{iso}>$. Acesso em: $01 \mathrm{abr}$. 2010. doi: 10.1590/S0006-87052008000200005.

COSTA, R.B. et al. Seleção simultânea para porte reduzido e alta produção de látex em seringueira. Bragantia, v.67, p.649654, 2008b. Disponível em: <http://www.scielo.br/ scielo.php?script =s ci_art text \& pid = S $0006-$ $87052008000300013 \& \operatorname{lng}=e n \& n r m=i s o>$. Acesso em: 01 abr. 2010. doi: 10.1590/S0006-87052008000300013.

GARCIA, C.H. Tabelas para classificação do coeficiente de variação. Piracicaba: IPEF, 1989. 12p. (Circular técnica, 171).

LIN, C.S.; BINNS, M.R. Relative efficiency of two randomized block designs having different plot size and numbers of replications and of plots per block. Agronomy Journal, v.78, p.531-534, 1986.

LOPES, S.J. et al. Tamanho de parcela para produtividade de grãos de sorgo granífero em diferentes densidades de plantas. Pesquisa Agropecuária Brasileira, v.40, p.525-530, 2005. Disponível em: $<$ http://www.scielo.br/scielo.php?script=sci_arttext\&pid=S0100-
204X2005000600001\&lng=en\&nrm=iso>. Acesso em: 01 abr. 2010. doi: 10.1590/S0100-204X2005000600001.

LÚCIO, A.D. et al. Classificação dos experimentos de competição de cultivares quanto a sua precisão. Pesquisa Agropecuária Gaúcha, v.5, p.99-103, 1999.

MEIER, V.D.; LESSMAN, K.J. Estimation of optimum field plot shape and size for testing yield in Crambe abyssinica Hochst. Crop Science, v.11, p.648-650, 1971.

OLIVEIRA, R.L. et al. Precisão experimental em ensaios com a cultura do feijão. Ciência e Agrotecnologia, v.3, n.1, p.113-119, 2009. Disponível em: <http://www.scielo.br/ scielo.php ? script=sci_arttext\&pid=S 1413 $70542009000100016 \& \operatorname{lng}=e n \& n r m=i s o>$. Acesso em: 01 abr. 2010. doi: 10.1590/S1413-70542009000100016.

OLIVEIRA, S.J.R. et al. Índice de heterogeneidade, coeficiente de variação e tamanho ótimo de parcelas em batata. Ciência Rural, v.36, p.1710-1716, 2006. Disponível em: <http:// www.scielo.br/scielo.php? script=sci_arttext\&pid=S0103$84782006000600007 \& \operatorname{lng}=$ en\&nrm=iso $>$. Acesso em: 01 abr. 2010. doi: 10.1590/S0103-84782006000600007.

PETEK, M.R. et al. Predição de valores genéticos aditivos na seleção visando obter cultivares de café mais resistentes à ferrugem. Bragantia, v.67, p.133-140, 2008. Disponível em: <http:// www.scielo.br/scielo.php? script $=$ sci_arttext $\&$ pid $=$ S0006 87052008000100016\&lng=en\&nrm=iso >. Acesso em: 01 abr. 2010. doi: 10.1590/S0006-87052008000100016.

RESENDE, M.D.V.; DUARTE, J.B. Precisão e controle de qualidade em experimentos de avaliação de cultivares. Pesquisa Agropecuária Tropical, v.37, p.182-194, 2007.

SMITH, H.F. An empirical law describing heterogeneity in the yields of agricultural crops. Journal of Agricultural Science, v.28, p.1-23, 1938.

STEEL, R.G.D. et al. Principles and procedures of statistics: a biometrical approach. 3.ed. New York: McGraw-Hill, 1997. $666 \mathrm{p}$.

VENCOVSKY, R. Herança quantitativa. In: PATERNIANI, E.; VIEGAS, G.P. (Ed.). Melhoramento e produção de milho. 2.ed. Campinas: Fundação Cargill, 1987. V.1, p.137214, 795p. 